DOI https://doi.org/10.30525/978-9934-26-046-9-37

\title{
ВПЛИВ РЕЦЕПТУРНОГО СКЛАДУ ПІСОЧНОГО ПЕЧИВА НА ФІЗИКО-ХІМІЧНІ ВЛАСТИВОСТІ ГОТОВИХ ВИРОБІВ
}

\author{
Олійник Н. В. \\ кандидат технічних наук, дочент, \\ доцент кафедри технологій харчових виробництв і ресторанного \\ господарства \\ Вищий навчальний заклад Укоопспілки «Полтавський університет \\ економіки і торгівлі» \\ м. Полтава, Украӥна \\ Наконечна Ю. Г. \\ кандидат технічних наук, \\ доиент кафедри технологій харчових виробництв і ресторанного \\ господарства \\ Вищий навчальний заклад Укоопспілки «Полтавський університет \\ економіки і торгівлі» \\ м. Полтава, Украӥна

\section{Гузевська I. I.} \\ спеціаліст вищої категорії, \\ викладач фахових дисииплін, \\ голова ииклової комісії спеціальності «Харчові технології» \\ ВСП «Полтавський фаховий коледж Національного університету \\ харчових технологій» \\ м. Полтава, Украӥна
}

На даний час урядом багатьох країн світу розробляються та реалізуються державні програми 3 покращення харчового статусу населення щодо виробництва харчових продуктів, які збагачені на фізіологічно-функціональні інгредієнти. Дана продукція конче необхідна для підтримки здоров'я та працездатності громадян, забезпечення гідного майбутнього через оздоровче харчування дітей та юнацтва, оскільки існує економічна криза та погіршується екологічна ситуація.

Найбільш перспективнимиє технології борошняних кондитерських виробів з використанням вторинної рослинної сировини. Метою таких технологій є збагачення комплексом вітамінів, мінералів, органічними 
кислотами, харчовими волокнами та іншими цінними компонентами харчування. Особливу увагу в цьому плані заслуговують відходи виноробного виробництва [1, с. 36].

Кісточки, шкірочки та залишки гребенів виноградних вичавок потужне джерело харчових волокон, поліфенолів, макро- та мікроелементів, вітамінів (РР, С, холіну) [2, с. 17].

Проблемами використання відходів виноградного виробництва у харчових технологіях в Україні займалися науковці Національнго університету харчових технологій (Київ), Харківського державного університету харчування і торгівлі (Харків), Донецького національного університету економіки і торгівлі ім. Туган-Барановського (Кривий Ріг), а саме: Дробот В.І., Самохвалова О.В., Касабова К.Р., ШидаковаКаменюка О.Г., Брикова Т.М., Гревцева Н.В., Городиська О.В., Буштрук І.В. Додавання відходів виноградного виробництва в різні харчові продукти, наприклад, макаронні вироби, борошняні та цукрові кондитерські вироби, хліб, дає можливість збагатити традиційну продукцію життєво важливими компонентами, надати їй оздоровчі властивості, а також підвищити якість [3, с. 6].

Враховуючи вищезазначене, можна зробити висновок, що порошки 3 кісточок винограду, відокремлених від виноградних вичавків, $\epsilon$ цінними та перспективними добавками у виробництві борошняних кондитерських виробів. Зважаючи на це, застосування таких порошків для розширення асортименту борошняних кондитерських виробів масового та функціонального призначення, $є$ актуальним.

Об'єктом досліджень у дослідженнях є технологія напівфабрикату пісочного основного та приготовленого на основі нього напівфабрикату із порошком із виноградних кісточок, а також фізико-хімічні показники. Предметом досліджень обрано напівфабрикат пісочний основний № 8 [4, с. 16].

В якості збагачувача використовували порошок із виноградних кісточок, що виробляється за ТУ У 10.8-34801551-004:2013 [5]ТОВ Оріон» (м. Одеса) під торговою маркою «Олео Віта».

У рецептурі напівфабрикату пісочного основного здійснювали заміну борошна на порошок із виноградних кісточок у кількості 8, 13, $18 \%$. Було досліджено готові пісочні напівфабрикати, приготовлені за стандартною рецептурою (контрольний виріб) та готові вироби з добавкою.

Для виробів із пісочного тіста вимогам стандарту повинні відповідати такі показники, як вологість, лужність, намочуваність, ламкість, розсипчастість. 
Оскільки до рецептури пісочного печива входять хімічні розпушувачі, доцільним було дослідження лужності контрольних та дослідних зразків. Відповідно до нормативної документації значення показника лужності печива не повинно перевищувати 2 град. Всі дослідні зразки за показником лужності відповідали ДСТУ 3781:2014.

Дані досліджень розсипчастості борошняних кондитерських виробів із пісочного тіста показали, що зі збільшенням кількості внесеної добавки розсипчастість виробів зменшується на 1,$2 ; 2,4 ; 7,4 \%$ відповідно для зразків із внесенням добавки $8,13,18 \%$. Це зумовлено тим, що порошок із виноградних кісточок має дрібнодисперсну структуру i у структурі печива щільно заповнює ії пори, що, в свою чергу, буде впливати також і на намочуваність.

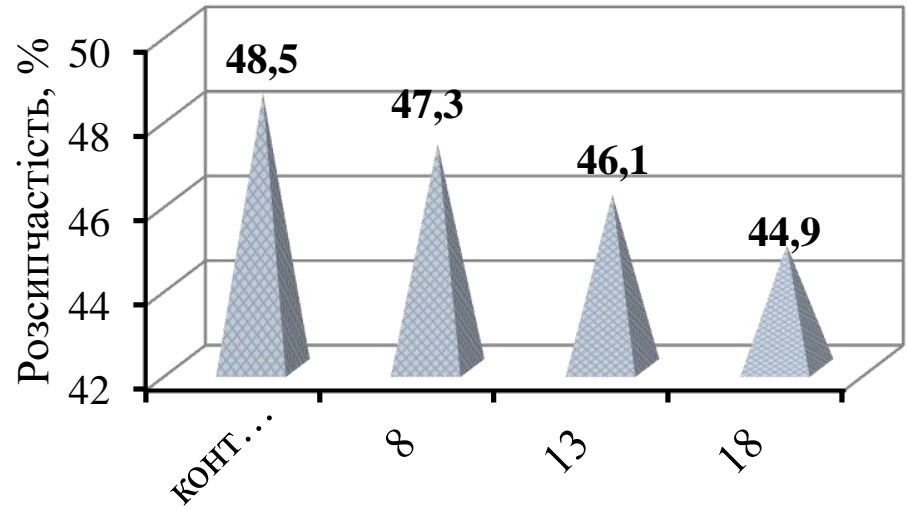

Вміст добавки, \%

Рис. 1. Діаграма дослідження зміни розсипчастості пісочного печива від кількості внесеної добавки

Намочуваність виробів із добавкою зменшується при збільшенні іiі вмісту у рецептурі. Встановлено, що зразки з додаванням 8 та $13 \%$ порошку виноградних кісточок мають показник намочуваності відповідно до вимог нормативної документації (за ДСТУ цей показник має бути не менше 100 \%). Намочуваність даних зразків менша, ніж намочуваність контрольного зразку на 5,7 та $11,85 \%$ і становить 143,4 та $137,25 \%$ відповідно. Намочуваність печива $318 \%$ добавки складає $105,2 \%$, що знаходиться майже на нижній межі нормативних вимог. 


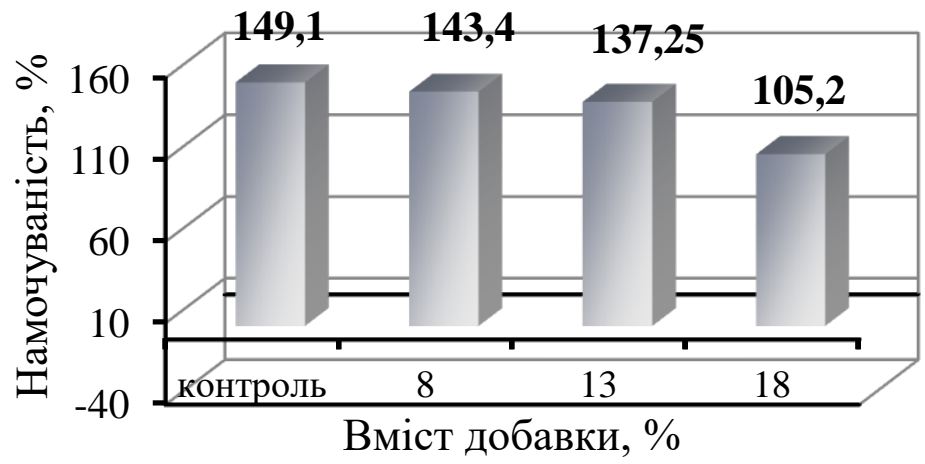

\section{Рис. 2. Діаграма зміни намочуваності пісочного печива за вмістом порошку із виноградних кісточок у рецептурі}

Ущільнення структури печива $з$ добавкою, зниження здатності до намокання та збільшення вологості зумовлюють зниження показника ламкості. При внесенні максимальної кількості добавки показник ламкості зменшується на 4,1\%. Це матиме негативний вплив на органолептичні показники пісочного печива.

Підсумовуючи вище зазначене можна сказати, що майже всі розроблені зразки за фізико-хімічними показниками відповідають вимогам ДСТУ, але найкращим зразком із розроблених є зразок № 2, в рецептурі якого заміна борошна на порошок із виноградних кісточок складає $13 \%$ оскільки додавання $18 \%$ добавки значно зменшує намочуваність та ламкість виробів, що негативно вплине на засвоєння продукту.

Проведені нами дослідження дозволяють стверджувати, що відповідно до запропонованої технології можливо створити вироби, які не поступаються за якісними показниками контрольним, а за деякими перевищують їх.

На основі проведених досліджень розроблено рецептуру і технологію печива «Родзинка» 3 додаванням $13 \pm 2$ \% порошку із виноградних кісточок від маси борошна. Основні параметри нової технології не відрізняються від традиційної. 


\section{Література:}

1. Батькова И. А., Яшина И. А., Макарова Н. В., Новикова М. Н., Смирнова Н. В. Влияние температуры сушки на химический состав и антиоксидантные свойства виноградных выжимок. Хранение и переработка сельхозсырья. 2014. № 2. С. 36-38.

2. Лисюк, Г. М., Верешко Н. В., Чуйко А. М. Нові напрями використання вторинних продуктів переробки винограду у виробництві борошняних виробів: монографія. Харків: ХДУХТ, 2011. 175 с.

3. Касабова К.Р., Гревцева Н.В., Шидакова-Каменюка О.Г., Омельченко О.В. Використання вторинних продуктів виноробного та пивоварного виробництва у технології здобного печива. Обладнання та технології харчових виробництв. 2017. № 35 (2017). С. 5-11.

4. Сборник рецептур мучных кондитерских и булочных изделий для предприятий общественного питания. Санкт-Петербург: Гидрометеоиздат, $1998.300 \mathrm{c}$.

5. ТУ У 10.8-34801551-004:2013. Порошки з рослинної олійної та кісточкової фруктової сировини харчові. Технічні умови Київ: Держспоживстандатр України, 2008. 12 с. 